\author{
Ks. Adam Skreczko \\ Uniwersytet w Białymstoku
}

\title{
ROLA KOŚCIOŁA W KSZTAŁTOWANIU KULTURY PEDAGOGICZNEJ RODZICÓW
}

\section{THE ROLE OF THE CHURCH IN SHAPING THE PEDAGOGICAL CULTURE OF PARENTS}

Parents bear the primary responsibility for educating their children. This task is an art which requires a lot of skills. In this respect, parents cannot rely merely on their inborn abilities. They should constantly seek to perfect and acquire pedagogical skills. However, educating children is a task for which few parents prepare in a systematic way. Oftentimes their conscious, intentional educational policies stand in contradiction to their actions and lifestyle, which renders them ineffective. This work contains a suggestion that the Church should also aid parents in raising their offspring. Unfortunately, few specialists concerned with this field mention the Church's activity in this regard. However, it should clearly be the role of the Church to organize counseling and the pedagogization of parents and future parents at the parishes, deaneries, and dioceses. This work shows that the Church has both the right and duty to do so.

\section{Wstęp}

Oceny kultury pedagogicznej rodziców obecnie dokonywane w Polsce są niezadowalające ${ }^{1}$. Tymczasem wielość sytuacji wychowawczych we współczesnej rodzinie, ich złożoność i zróżnicowanie, wymaga wysokiego poziomu rodziców w tym zakresie. Istnieje więc pilna potrzeba pedagogizacji rodziców, czyli popularyzowania wiedzy związanej z rozwojem i wychowaniem dzieci.

Realizatorem kształcenia pedagogicznego rodziców i potencjalnych rodziców jest głównie szkoła. Pomagają jej w tym domy kultury, poradnie pedagogiczne, media, samorządy terytorialne oraz inne instytucje. Niewielu niestety

${ }^{1}$ Por. H. Cudak, Edukacja pedagogiczna rodziców - ważny element systemu polityki prorodzinnej, w: M. Chymuk, D. Topa (red.), Edukacja prorodzinna, Kraków 2000, s. 58-65. 
pedagogów zajmujących się tą problematyką wymienia Kościół², mimo że stara się on iść wraz z człowiekiem po tylu różnych drogach jego ziemskiego życia, a także „uważa służbę rodzinie za jedno ze swych najistotniejszych zadań i w tym znaczeniu, zarówno człowiek, jak i rodzina, są »drogą Kościoła«" (List do Rodzin, 2). Kościół niesie rodzinom nadzieję płynącą z Ewangelii i na jej bazie ukształtowany system postulatów wychowawczych. Troska Kościoła o małżeństwo i rodzinę znajduje się w samym centrum jego pastoralnej działalności".

W niniejszym opracowaniu pragniemy zając się zagadnieniem roli Kościoła katolickiego w podnoszeniu kultury pedagogicznej rodziców i całego społeczeństwa. Omówiona zostanie sama potrzeba pedagogizacji rodziców, jej niektóre treści oraz sposoby ich przekazywania.

\section{Potrzeba kształtowania kultury pedagogicznej rodziców}

Na kulturę pedagogiczną rodziców składa się „,całokształt ich postępowania z dzieckiem, organizacja życia w rodzinie, jego atmosfera i wytworzony jego styl"4. Stanisław Kawula uważa, że celem pedagogizacji jest bezpośrednia i pośrednia pomoc rodzicom wich oddziaływaniach wychowawczych przez podniesienie stopnia ich refleksyjności, wzbogacenie świadomości pedagogicznej, co w konsekwencji poprawia funkcjonowanie rodziny pod względem wychowawczym". Pedagogizacja rodziców polega więc na dostarczeniu rodzicom fachowej wiedzy na temat świadomego wychowania dzieci ${ }^{6}$. Rodzice powinni uczyć się mądrze wychowywać swoje dzieci, by wyrosły na odpowiedzialnych ludzi. Pedagogizacja rodziców jest niezwykle ważna, ponieważ błędy wychowawcze są bardzo trudne do naprawienia, wobec czego wpływają na całe życie

"Czynią to m.in.: P. Poręba, Pedagogizacja rodziców, „Studia Warmińskie" 6 (1969), s. 423-487; A. Lepa, U podstaw duszpasterskiej pedagogizacji rodziców, „Katecheta” 6 (1980), s. 250-255. H. Cudak opublikował wyniki badań na temat roli Kościoła w pedagogizacji rodziców w naszym kraju: H. Cudak, Rola ośrodków nieszkolnych w kształtowaniu kultury pedagogicznej rodziców, Kielce 1997, s. 138-183. Stwierdził tam, że „Zagadnienie wpływu Kościola na współczesne społeczeństwo nie zawsze było dostrzegane i doceniane przez pedagogów w naszym kraju” (s. 161). W podsumowaniu natomiast zauważył, że „rola Kościoła jako instytucji wychowawczej w kształtowaniu kultury pedagogicznej jest niezwykle istotna, bo zadania przez nią realizowane w stosunku do dzieci, młodzieży i wspólnot rodzinnych są planowe, świadome i systematycznie potwierdzane" (s. 183).

${ }^{3}$ Por. M. Przykucki, Inicjatywy duszpasterskie Kościoła na rzecz rodziny, „Znaki czasu” 5 (1987), nr 1, s. 20-38; S. Stefanek, Dokumenty Kościoła o rodzinie, w: K. Klauza (red.), Rodzina środowiskiem życia, Częstochowa 1994, s. 191-219; J. Śledzianowski, Kościót katolicki $w$ stużbie rodzinie, w: $\mathrm{H}$. Cudak (red.), Wychowanie $w$ rodzinie wspótczesnej $w$ świetle zagrożeń i wsparcia społecznego, Piotrków Trybunalski 1999, s. 385-397; A. Skreczko, Troska Kościoła katolickiego w Polsce o rodzinę po drugiej wojnie światowej, „Rocznik Teologii Katolickiej" UwB 2 (2003), s. 41-73.

${ }^{4}$ M. Grochociński, Kultura pedagogiczna rodziców, w: M. Ziemska (red.), Rodzina i dziecko, Warszawa 1986, s. 302.

${ }^{5}$ Por. S. Kawula, Pedagogizacja rodziców, w: W. Pomykało (red.), Encyklopedia pedagogiczna, Warszawa 1993, s. 581.

${ }^{6}$ A. Skreczko, Znaczenie ciagłej pedagogizacji rodziców dla wychowania prorodzinnego dziecka, w: M. Chymuk, D. Topa (red.), Edukacja prorodzinna, Kraków 2000, s. 240-246. 
człowieka. Jej zadaniem jest spowodowanie postępowania rodziców w wychowaniu przede wszystkim według metod i umiejętności pedagogicznych, a nie tylko intuicji i tradycyjnych wzorców.

Panuje niestety powszechne przekonanie, że rodzice umieją wychowywać przez sam fakt, że są rodzicami, sami najlepiej wiedzą, co jest ich dziecku potrzebne i jak z nim postępować, stąd też nie potrzeba im cudzej mądrości. To prawda, że rodzice wychowuja w rodzinie przez samo przebywanie ze swoim dzieckiem w bliskim i jedynym kontakcie uczuciowym i stwarzaja mu tak ważną rzeczywistość domu. Ale prawdą jest również fakt, że zadania rodzicielskie wymagają nieporównanie większych przygotowań niż rola wychowawcy sensu stricto. Rodzice powinni zdawać sobie sprawę, że wywierają trwały wpływ na swoje dziecko. Przez swoje błędy często powodują braki wychowawcze u swoich dzieci, które później jest trudno lub wręcz nie można naprawić. Ważnym więc zadaniem jest uświadomienie rodzicom najpierw samej potrzeby korzystania z systematycznej pedagogizacji.

Potrzeba pedagogizacji płynie także z potrzeby umocnienia rodziny stającej wobec rozmaitych współczesnych zagrożeń. Lista ich niestety nieustannie rośnie ${ }^{7}$ Chodzi tu nie tylko o obronę przed występującymi zagrożeniami, ale nade wszystko o promowanie przez Kościół prawdziwych wartości budujących rodzinę i umacniających ją w ważnej dziedzinie wychowania. Wychowanie w czasach współczesnych staje się sprawą wiedzy, umiejętności i doświadczenia. Podlega ono uwarunkowaniom wewnątrzrodzinnym takim, jak: struktura rodziny, płeć, praca zawodowa matek, poziom wykształcenia i religijności oraz uwarunkowaniom zewnątrzrodzinnym takim, jak: typ społeczno-zawodowy rodziny, bezrobocie, styl życia, akceleracja rytmu życia, zagrożenia ze strony ideologii antypedagogiki, a także miejsce zamieszkania.

W okresie dokonujących się przemian cywilizacyjnych i kulturowych nastąpiło niepokojące osłabienie wychowawczych funkcji rodziny. Konsekwencje tych zmian obserwuje się m.in. w zaburzeniach rozwojowych dzieci, w rosnącej patologii środowiska rodzinnego, a również w bardzo częstym zagubieniu i osamotnieniu przeżywanym w rodzinie, szkole, grupie rówieśników, w tłumie innych, równie samotnych, osób.

Interesuje nas szczególnie pedagogizacja rodziców w sferze wychowania religijnego ${ }^{8}$. Istnieje wielka potrzeba wsparcia rodziny przez Kościół, w nale-

${ }^{7}$ Por. F. Adamski, Wspótczesne zagrożenia rodziny, „Ateneum Kapłańskie” 87 (1995), nr 516, s. 217-226; L. Mościcka, Zagrożenia dla prawidtowego funkcjonowania rodziny, w: L. Mościcka (red.), Prace pedagogiczne, Wrocław 1991, s. 97-197; H. Cudak (red.), Problemy i zagrożenia wspótczesnej rodziny w Polsce, Piotrków Trybunalski 1998.

${ }^{8}$ Por. T. Makowski, Religijno-moralna żywotność wspótczesnej rodziny polskiej katolickiej. Refleksje socjologiczno-pastoralne, „Studia Gnesnensia” 3 (1977), s. 109-188; L. Corradini, Wychowanie religijne w rodzinie, „Communio” 2 (1982), z. 5, s. 51-63; K. Bełch, Życie religijne w rodzinie polskiej, „Zeszyty Naukowe KUL” 24 (1981), nr 2-4, s. 43-60; A. Jagiełło, Rodzina a rozwój postaw religijnych, Wrocław 1987; C. Rogowski, Przekaz wiary w sytuacji wspótczesnego pluralizmu religijno-pedagogicznego, „Ateneum Kapłańskie” 86 (1994) nr 513-514, s. 192-202. 
żytym przeciwdziałaniu rosnącym zagrożeniom i podjęciu nowych wyzwań'. W historii Polski były okresy wzmożonej troski Kościoła o małżeństwo i rodzinę, szczególnie w zakresie jej życia religijnego. Miało to miejsce wtedy, gdy wzrastała liczba i intensywność zagrożeń. Następowała wówczas mobilizacja sił, szukano odpowiednich metod przezwyciężenia pojawiającego się kryzysu, aby ratować rodzinę ${ }^{10}$.

Warto tu wspomnieć o różnorakich inicjatywach duszpasterskich podejmowanych w przeszłości przez Kościół katolicki w Polsce dla utrzymania i umocnienia chrześcijańskiego wychowania w rodzinie. Okresem szczególnej mobilizacji i intensywnej pracy Kościoła na rzecz małżeństwa i rodziny była Wielka Nowenna Tysiąclecia ${ }^{11}$. Ówczesne skupienie uwagi duszpasterstwa na problematyce rodziny w różnych jej aspektach wyrażało się w trosce o życie zgodne z planami Bożymi i zachowanie religijnego, chrześcijańskiego charakteru, bo od tego przecież zależy nie tylko przyszłość Kościoła i narodu, lecz także zbawienie każdego pojedynczego człowieka. Współczesność rodzi podobną potrzebę.

\section{Prawo Kościoła do wychowywania rodziców}

Działalność Kościoła katolickiego w podnoszeniu kultury pedagogicznej rodziców nazwiemy „duszpasterską pedagogizacją rodziców”. Dlatego „duszpasterska”, ponieważ kierowana jest przez katechetów oraz duszpasterzy i odbywa się zasadniczo w ramach parafialnej pedagogii duszpasterskiej, gdyż na parafii głównie spoczywa zadanie wyrażone w następujących słowach Jana Pawła II: „istnieje pilna potrzeba odtworzenia chrześcijańskiej tkanki społeczności ludzkiej” (Familiaris consortio, 42).

Kościół ma prawo nadprzyrodzone do wychowywania swych wiernych. Płynie ono ztytułu: a) misji nauczycielskiej, zleconej przez Chrystusa w słowach: „Idźcie więc i nauczajcie wszystkie narody udzielając im chrztu w imię Ojca i Syna i Ducha Świętego; uczcie je zachowywać wszystko, co wam przekazałem" (Mt 28,19); b) misji zbawiania dusz, czyli macierzyństwa duchowego. „Kto uwierzy i przyjmie chrzest, będzie zbawiony; a kto nie uwierzy, będzie potępiony" (Mk 16,16) ${ }^{12}$. Wiele razy na ten temat wypowiadał się Kościół katolicki w swoich dokumentach, głównie począwszy od wieku XIX, poprzez Sobór Watykański II, aż do czasów obecnych. Wśród różnych znaczeń samego pojęcia „wychowanie” w Kościele, na czoło wysuwa się dziś rozumie-

9 A. Jagiełło, Kultura religijna rodziny a postawy religijne członków, „Colloquium Salutis. Wrocławskie Studia Teologiczne”, t. 18-19 (1986-87), 281-306.

${ }^{10}$ Por. S. Wierzchosławski, Rodzina w okresie transformacji demograficznej $i$ społeczno-ekonomicznej, w: P. Kryczka (red.), Rodzina w zmieniajacym się społeczeństwie, Lublin 1997, s. 86.

${ }^{11}$ Por. A. Skreczko, Troska Kościoła katolickiego w Polsce o matżeństwo i rodzine w okresie Wielkiej Nowenny Tysiqclecia (1957-1966). Studium teologiczno-pastoralne, Białystok 2002.

12. Por. S. Kunowski, Podstawy wspótczesnej pedagogiki, Warszawa 1993, s. 106. 
nie tego terminu jako „wzrastania w pełnię człowieczeństwa, w pełnię życia. Pełnię tę ma człowiek z Boga, w Chrystusie, za pośrednictwem Ducha Świętego" ${ }^{13}$. Kościół ma wspomagać rodzinę, pierwsze środowisko wychowawcze, w realizacji tej pełni. Jest powołany nie tylko do świadczenia pomocy rodzicom w ich osobistym uświęceniu, ale również w wychowaniu religijnym dzieci.

Wspomniane prawo Kościoła do wychowania zarówno religijnego, jak też czysto ludzkiego, jest na ogół właściwie rozumiane i przyjmowane przez chrześcijan ${ }^{14}$. Nie zawsze jednak należycie współpracują podstawowe środowiska wychowawcze: rodzina i szkoła z Kościołem w realizacji tego prawa, co jest niewątpliwie jedną z przyczyn dezorientacji wychowanków w świecie wartości i zagubienia w życiu.

\section{Treści duszpasterskiej pedagogizacji rodziców}

Po ukazaniu fundamentu powołania wychowawczego Kościoła, zajmiemy się treściami, które winny być przekazywane rodzicom w ramach duszpasterskiej pedagogizacji, aby potem poszukać najskuteczniejszych sposobów realizacji tego zadania. Ze względu na ograniczone ramy tego opracowania, weźmiemy pod uwagę jedynie niektóre aspekty szerokiego i złożonego procesu pedagogizacji.

\section{a. Świadomość zobowiązań płynących z sakramentu małżeństwa}

Ojcostwo i macierzyństwo są nie tylko sprawą ludzkiej wolności, ale przede wszystkim aspektem powołania wpisanego w miłość małżeńską, przeżywanego ze szczególną odpowiedzialnością wobec Boga za przyjęcie dzieci jako Jego daru ${ }^{15}$.

Małżonkowie chrześcijańscy, poprzez sakrament małżeństwa, zostali powołani do rodzicielstwa, czyli współpracy z Bogiem w jego stwórczym dziele, jakim jest dziecko ${ }^{16}$. Trzeba rodzicom chrześcijańskim zdecydowanie przypominać, że nie są panami życia, ale sługami bożych zamiarów ${ }^{17}$. Świadomość tego posłannictwa pomaga im poświęcić się dziełu wychowania dzieci z ufnością i poczuciem odpowiedzialności wobec Boga za troskę o wzrost

${ }^{13}$ A. Rynio, Integralne wychowanie w myśli Jana Pawta II, Lublin 2004, s. 108.

${ }_{14}$ Por. R. Murawski, B. Duszyński, Biblijno-teologiczne podstawy wychowawczego postannictwa Kościoła, w: Seminare. Poszukiwania naukowo-pastoralne, Ląd 1983, s. 205.

${ }^{15}$ Por. R. Sztychmiler, Pojęcie matżeństwa chrześcijańskiego, „Roczniki Nauk Prawnych” 1-2 (1991-92), s. 29-52.

${ }^{16}$ „W sakramencie małżeństwa rodzice otrzymują łaskę i zadanie chrześcijańskiego wychowania swoich dzieci, wobec których świadczą i którym przekazują równocześnie wartości ludzkie i religijne" (Christifideles laici, 62).

${ }^{17}$ Por. J. Nagórny, „Ewangelia życia” wobec „kultury śmierci”, w: A. Młotek, T. Reroń (red.), Życie - dar nienaruszalny. Wokót encykliki „Evangelium vitae”, Wrocław 1995, s. $168-169$. 
„dziecka Bożego"18. Rodzice więc mają obowiązek wprowadzenia dziecka w nadprzyrodzoną rzeczywistość, potencjalnego nawiązywania i rozwijania kontaktu z Bogiem. Rozwój moralny i religijny dziecka powinien stanowić istotną rolę w procesie wychowawczym. Niestety jednak, w obecnych czasach rozwój ten schodzi na plan dalszy, a rodzice więcej uwagi poświęcają rozwojowi umysłowemu i fizycznemu, zaniedbując rozwój duchowy.

Odpowiedzialne rodzicielstwo jest jednym z głównych zadań małżeństwa. Potrzeba odpowiedzialności w dziedzinie rodzicielstwa może być w pełni zrozumiana tylko w świetle Objawienia. Prawda o rodzicielstwie została objawiona "od początku» przez fakt, że była umieszczona w samym centrum stworzenia. Właśnie w tajemnicy stworzenia Bóg jawi się jako Ojciec każdego życia, a ojcostwo człowieka jawi się jako misja współpracy ze stwórczym aktem Boga, który sprawił, że człowiek przychodzi na świat w rodzinie. Ta prawda winna być uznana przez człowieka w duchu Maryi i Józefa, czyli w posłuszeństwie wiary ${ }^{19}$. Wzór Maryi i Józefa pozwala twierdzić, iż odpowiedzialne rodzicielstwo małżonków wszystkich czasów znajduje swój początek i swoje kryterium prawdziwości w pierwszym artykule wiary: Wierzę w Boga Ojca i Stworzyciela. W tym duchu należy troszczyć się nie tylko o fizyczne poczęcie i narodzenie dziecka, ale i duchowe.

Rodzice ustawicznie kształtują swą osobowość w trakcie realizacji powołania rodzicielskiego. Przyjście na świat dziecka, szczególnie pierwszego, jest ogromnym wyzwaniem dla małżonków. Muszą bowiem wejść w pełnienie nowej roli społecznej, roli matki i ojca, a każda zmiana roli społecznej jest trudna i wymaga przygotowania. Role rodzicielskie są rolami żywicieli, opiekunów i wychowawców, przewodników duchowych. Każdy z tych elementów jest tak samo ważny. Pominięcie któregokolwiek z nich wpływa zawsze negatywnie na harmonijny rozwój dziecka. Dlatego zrozumiałe jest skupienie uwagi duszpasterskiej pedagogizacji rodziców głównie na wymiarze duchowym, ale bez pomijania i lekceważenia pozostałych sfer.

Współcześnie role matki i ojca są częściowo komplementarne, częściowo zaś zgodne i rodzice zamiennie wykonują zadania opiekuńcze i wychowawcze. Wspomniane role komplementarne wiążą się przede wszystkim z płcią oraz kształtowaniem się podstaw biologicznych i społecznych ról męskich i kobiecych. Od męskiej roli ojca oczekuje się więc dzielności, siły, zaradności, odpowiedzialności za podejmowane decyzje i zadania, czuwania nad przestrzeganiem norm moralnych, społecznych, stwarzania oparcia emocjonalnego i materialnego dla żony i dzieci. Od kobiecej roli matki oczekuje się zaś ekspresji uczuć, ciepła, wyrozumiałości, życzliwości, zrozumienia, zaspokajania

${ }^{18}$ Warto w tym miejscu przywołać słowa etyka: „Rodzą, Jego [Boga] i swoje dziecko - wraz z Nim, w akcie samooddania! Baczność zatem! Decydując się wstąpić na szlak "przyjścia Pana», transitus Domini”. T. Styczeń, Dar życia i Jego Dawca, w: K. Majdański (red.), Dar ludzkiego życia. Humanae vitae donum, Lublin 1991, s. 73.

1." Por. J. Jełowiecka, Matka Boża w nauczaniu Prymasa Tysiqclecia, w: S. Grzybek (red.), Maryja Matka Narodu polskiego, Częstochowa 1983, s. 228-229. 
potrzeb innych, tworzenia atmosfery rodzinnej, wprowadzania dziecka w krag szerszej rodziny i tradycji. Podobnie w sferze wychowania religijnego każde z rodziców ma swoją ważną i komplementarną rolę.

Bardzo ważnym zagadnieniem jest nastawienie rodziców do swego powołania rodzicielskiego, do roli rodzicielskiej. Kształtowanie się stosunku do dziecka, wywiązywanie się z obowiązków rodzicielskich jest efektywne wtedy, kiedy każde z rodziców akceptuje się w tej nowej roli rodzicielskiej, kiedy rodzice mają przeświadczenie o jej ważności w rodzinie, Kościele i społeczeństwie, kiedy w pełni identyfikują się z nią i mają świadomość, że jej pełnienie to realizowanie celów rodziny jako całości.

Tutaj też rozpoczyna się praca rodziców nad sobą w celu kształtowania światopoglądu i osobowości według wybranego wzoru, co w pedagogice określa się procesem personalizacji. U ludzi dorosłych jest to głównie własna praca formacyjna, wymagająca wysiłku i systematyczności, wspierana pomocą bożej łaski, pracą ewangelizacyjną i duszpasterską Kościoła, stanowiąca oddziaływanie formacyjne przez całe ich życie.

\section{b. Wiedza o dziecku}

Znajomość dziecka, tak nieodzowna dla jego prawidłowego wychowania, jest rzeczą niełatwą. Dotyczy ona wszystkich jego procesów rozwojowych, czyli zachodzących w nim zmian progresywnych, wymagających zrozumienia ze strony rodziców ${ }^{74}$. Nie znający tych prawidłowości rodzice są narażeni na popełnianie poważnych błędów wychowawczych, biorąc często normalne objawy rozwoju za wypaczenia.

Znajomość dokładna faz rozwoju dziecka, liczenie się z ich prawami i prawidłowościami, pozwoli rodzicom w porę rozpoznawać czy dziecko rozwija się normalnie, czy też jest opóźnione w rozwoju i wymaga stosowania odpowiednich środków zaradczych.

Wyodrębnienie różnych jakościowo okresów rozwojowych człowieka zakłada określoną koncepcję rozwoju jego religijności, wpływa na strukturę przeżyć religijnych, mechanizmy rozwoju, a przede wszystkim na prawidłowość przeobrażeń, zachodzących w poszczególnych okresach. Dobra znajomość poszczególnych okresów religijności pomaga w podejmowaniu odpowiednich działań wychowawczych, w tym wychowania modlitewnego dostosowanego do poziomu rozwoju religijnego.

Rodzice zobowiązani są zrodzone potomstwo wychować, aby mogło ono rozwinąc się w sposób właściwy człowiekowi zdolnemu włączyć się do życia społecznego. Jawi się więc tu problem, który może zostać zawarty w pytaniu: na kogo rodzice winni wychowywać swoje dziecko?

Wychowanie polega na harmonijnym ukształtowaniu osoby w zakresie jej wrodzonych właściwości fizycznych, intelektualnych, społecznych, moralnych 
i religijnych ${ }^{20}$. Kształtowanie to powinno zmierzać do celu ostatecznego człowieka, uwzględniając dobro społeczeństwa i Kościoła ${ }^{21}$. W praktyce codziennej rodzice wierzący celowość wychowania sprowadzają często do ogólnikowego postulatu wychowania dziecka na „uczciwego człowieka” czy „dobrego katolika”. Jednak nie zawsze podkładają pod te pojęcia właściwe treści. Rodzice wyrażają pragnienie, będące zarazem jakby programem wychowawczym, aby np. syn w przyszłości „nie kradł", „nie pił", „nie utracił wiary". Sytuacja taka wymaga od duszpasterzy i katechetów nauczenia rodziców należytego rozumienia ideału wychowania chrześcijańskiego, który w sferze codziennej praktyki stałby się dla rodziców modelem całej ich pedagogii. Ideał wychowania stanowi podstawowy punkt odniesienia do ustalenia poprawności oddziaływań wychowawczych podejmowanych w następstwie jego przyjęcia.

Ideałem chrześcijańskiego wychowania jest osiąnnięcie pełni człowieczeństwa, jak to już zostało wyżej powiedziane. Tak więc kościelna nauka o wychowaniu może być ujęta w ramy żywej pedagogii wiary, wiążącej człowieka z Bogiem i z ludźmi w osobie Jezusa Chrystusa. Cechy idealnego chrześcijanina nakreśla wyraźnie soborowa Deklaracja o wychowaniu chrześcijańskim „Gravissimum educationis”. Jest nim człowiek nowy, żyjący „w sprawiedliwości i świętości prawdy" i doskonały „na miarę wielkości według Pełni Chrystusa" (Ef 4,13), a ponadto gotowy do współdziałania w chrześcijańskim kształtowaniu świata - dla „dobra całej społeczności" (DWCH, 2). Idealny chrześcijanin wrażliwy jest na aktualne potrzeby i oczekiwania Kościoła zarówno w skali swojej parafii, jak i całego partykularnego Kościoła w Polsce. Cechy chrześcijanina doskonałego współtworzą na użytek wychowania współczesny model osobowości. Z wydatną pomocą rodzicom spieszy tu teologia, która w rozważaniach nad człowiekiem nie ogranicza się do pytania, jakim on jest, lecz, idąc dalej, wskazuje na ludzkie możliwości i udziela pewnej odpowiedzi na pytanie, kim człowiek może się stać.

Stałe odwoływanie się w ramach pedagogizacji do ideału wychowania chrześcijańskiego ułatwi rodzicom nie tylko bliższe poznanie tego ideału i podporządkowanie mu ogółu działań wychowawczych, lecz ponadto pozwoli im znacznie pogłębić świadomość pedagogiczną, kształtując w nich ducha odpowiedzialności za dzieło wychowania z wszystkimi jego skutkami i konsekwencjami.

\section{c. Wiedza o rodzicach jako wychowawcach}

Prawidłowe wychowanie dziecka w ogóle, a zwłaszcza w pierwszych latach jego życia, wymaga także posiadania informacji o wychowujących rodzicach. Powinni oni, dzięki pedagogizacji, uświadomić sobie własną odrębność psychiczną oraz uświadomić sobie potrzebę ustawicznego wzbogacania swej

${ }^{20}$ Por. P. Poręba, Wychowanie religijne w rodzinie, w: F. Adamski (red.), Miłość, matżeństwo, rodzina, Kraków 1981, s. 411-428.

${ }^{21}$ Por. T. Sikorski, Rodzina jako źródto ksztattowania człowieka. Od myśli Karola Wojtyty do nauczania Jana Pawta II, „Chrześcijanin w Świecie” 12 (1980) nr 10, s. 18-28. 
osobowości, której bogactwo decyduje w dużej mierze o sukcesie wychowania dziecka. Także wysoki poziom moralno-religijny rodziców jest najlepszą gwarancją duchowego rozwoju ich dziecka. Ten odpowiednio wysoki poziom moralno-religijny rodzice mogą osiągnąc przez ustawiczne kształcenie religijne, które dzisiaj realizuje m.in. katecheza dorosłych. Właściwy poziom duchowy rodzice osiągają wtedy, gdy wypełnianiem obowiązków wynikających z wiary dadzą wyraz swoim przekonaniom religijnym.

Aby dziecko skutecznie wprowadzić w życie religijne, wymaga się od rodziców autentyczności, szczerości i prawdy. Zdarza się czasem, że rodzice czują się niekompetentni jako osoby świeckie do rozmawiania o Bogu i zostawiają dzieciom swobodę wyboru, gdy te dorosną. Niektórzy rodzice zmuszają dzieci do religijnych praktyk, stając się dla nich jedynym autorytetem w tej dziedzinie. Jednak obydwa te sposoby są niedobre, ponieważ dziecko nie może wybierać, kiedy nie zna religii, a rodzice nie mogą być dla dziecka wzorem ostatecznym. Również dziecko może, poprzez swoją ciekawość i zadawanie pytań odnośnie do religii, wpłynąć na wzrost wiary rodziców. „Od postawy rodziców a zwłaszcza ojca, w stosunku do dziecka, szczególnie w pierwszych latach życia, będzie zależeć, czy pojęcie Bóg skojarzy się dziecku z najlepszym, kochającym, troskliwym i czułym Ojcem, czy też przeciwnie - z kimś siejącym strach, przerażenie, a może i niechęć. Taki negatywny obraz Boga może na długie lata zaciążyć na religijności dziecka. Dzieci, które po każdym przewinieniu są karane, mają częściej fałszywy obraz Boga - „Boga-żandarma«. Dzieci, których rodzice raczej tłumaczą im, mają częściej obraz Boga kochającego"'22. Wychowanie religijne zmierza do tego, aby dziecko trwale zespoliło się z Bogiem, żyło w łasce poprzez poznanie Go, uczuciowe przeżywaznie w miłości i dawanie o nim świadectwa życia. Chodzi o to, aby wykształcić w dziecku obraz Boga kochającego, który daje poczucie bezpieczeństwa. To poznanie, przeżywanie i wyrażanie Boga w życiu zależne jest od psychicznych możliwości dziecka, które rozwijają się w nim stopniowo. Dlatego rodzice winni kierować się stosunkiem przychylności wobec swojego małego dziecka, uważając je za cząstkę nie tylko swoją, ale też za wartościową cząstkę społeczeństwa i Ludu Bożego.

\section{d. Wiedza o wychowaniu}

Rodzice mają dwa podstawowe obowiązki wobec własnych dzieci: urodzenia i wychowania ${ }^{23}$. Od nich wymagana jest świadomość wychowawcza, która pozwoli im dostrzec ich wielkie obowiązki wobec dziecka. Samego wychowania nie mogą uważać za tresurę, ale za proces, serię zmian zachodzących w wychowaniu przy współudziale obydwu stron: wychowującej i wychowywanej. Papież Jan Paweł II w Liście do Rodzin (n. 16), odpowiadając na

\footnotetext{
2"2 Tamże, s. 274.

${ }^{23}$ Cz. Strzeszewski, Katolicka Nauka Społeczna, Lublin 1994, s. 416.
} 
pytanie: „na czym polega wychowanie?” stwierdza, że jest ono „obdarzaniem człowieczeństwem - obdarzaniem dwustronnym”. Tak więc wychowanek, zgodnie z tym stwierdzeniem, staje się również podmiotem, a nie tylko przedmiotem oddziaływań wychowawczych. On także obdarowuje, czyli wychowuje swego wychowawcę. Relacja wychowawcza ma więc być dwupodmiotowa ${ }^{24}$.

Ważne znaczenie dla rozwoju religijnego dziecka ma modlitwa rodzinna, w której biorą udział rodzice i dzieci, gdyż to w niej Chrystus obiecał swą obecność (por. Mt 18,19n.). Poza modlitwą istotne znaczenie ma też stopniowe wprowadzanie dziecka w uczestnictwo we Mszy św. oraz uczynki miłości i dobroci wobec innych ludzi, a także rozmawianie o religii i Bogu. „To, co mówi się małemu dziecku o Bogu musi być tak formułowane, aby później nie potrzeba było odrzucać i zmieniać, ale tylko uzupełniać i poszerzać”'5.

Jednym z błędów, występujących w wychowaniu religijnym ze strony rodziców jest oddzielenie wiary od życia. Nie powinni oni zachowywać się tak, jakoby ich religijność wyczerpywał tylko pacierz i Kościół, a życie nie miało nic wspólnego $\mathrm{z}$ wiarą. Ważną rzeczą jest, aby dzieci widziały i czuły, że w codziennym życiu rodziców obecny jest Bóg. Rodzice powinni starać się, głównie przez przykład, pokazywać dzieciom i młodzieży, że wiara to nie dodatek do życia, ale czynnik wprowadzający ład i celowość w całe działanie człowieka, poczynając od zabawy, odpoczynku i pracy, a kończąc na uczestnictwie w sakramentach.

Szczególnego omówienia wymaga stosowanie metod i środków w wychowaniu dziecka przez rodziców. Ponieważ każde z nich stosuje swoiste metody wychowania należy, informując ich, ogólnie powiedzieć o metodach właściwych i niewłaściwych. Metoda właściwa winna uwzględniać możliwości dziecka w danym okresie jego rozwoju, jak też wymagania stawiane mu przez rodziców, oddziałujących pozytywnie i wyzwalająco na aktywność dziecka. Z metodą pozytywną łączy się metoda zapobiegania, profilaktyczna, metoda usuwania okazji niebezpiecznych dla dziecka. Należy przy tym dziecku spokojnie wyjaśnić i wyłumaczyć powód, dla którego nie wolno czegoś czynić i dlaczego należy czynić inaczej. Należy także rodziców przestrzec przed metodami niewłaściwymi takimi, jak: nieznajomość możliwości dziecka i stawianie mu nadmiernych wymagań, stosowanie nadmiernego liberalizmu, stosowanie ciągłych nakazów i nagan, powodujących zahamowania jego aktywności, stosowanie nakazów i zakazów bez wyjaśnień w momencie, kiedy dziecko już czuje tego potrzebę. Przede wszystkim zły przykład rodziców wprowadza zamęt w rozeznanie dziecka i niszczy proces wychowania u samego jego podłoża. Rodzice chrześcijańscy, prócz metod i środków naturalnych, dysponują także środkami nadprzyrodzonymi. Korzystanie ze Słowa Bożego, kultu

\footnotetext{
${ }^{24}$ Por. A. Skreczko, Znaczenie dwupodmiotowej relacji w wychowaniu dziecka, „Studia nad Rodziną" 4 (2000), nr 1, s. 123-129.

${ }^{25}$ E. Wójcik, Trzeba kochać, żeby żyć, Warszawa 2000, s. 280.
} 
liturgicznego i innych pomocy duchowych pomoże im dostrzec ich wielka odpowiedzialność przed Bogiem za wychowanie dzieci.

Przekazywanie rodzicom elementarnej wiedzy na temat natury i charakteru wychowania w rodzinie staje się bardzo pilne i nieodzowne, ponieważ nadál zauważa się wyraźny niedostatek publikacji rozpatrujących problemy struktury i funkcjonowania rodziny „normalnej”. Ścisły związek, zachodzący między strukturą środowiska rodziny i jego wychowawczym funkcjonowaniem, analizowany bywa najczęściej w pracach poświęconych różnorakim odchyleniom od poprawności, jakie przejawia pedagogia współczesnej rodziny.

Rodzice nie mogą swemu dziecku dać wiary, mogą jednak promieniować wiarą i to stwarza w potomstwie gotowość do wiary, jakkolwiek ta gotowość nie u wszystkich jest jednakowa ${ }^{26}$. Dzieci muszą wiedzieć i wyczuwać, że dla rodziców ogromne znaczenie ma istnienie Boga i że jest Ktoś, komu ufają nawet w najtrudniejszych momentach swego życia. W wychowaniu dziecka bywa czasem i tak, że poprzez działanie łaski Bóg sam wewnętrznie pociąga je ku religii, nawet jeśli rodzice są niepewni w swojej wierze. „Religijności nie przekazuje się metodą, jak gdyby napełniania naczynia, ale metodą jakby zapalania świecy od już płonącej świecy. Ogólnie mówiąc, celem wprowadzenia w zasady religijne jest nie tyle wiedza, (choć ma ona swoje znaczenie), ile miłość do Boga i bliźnich i trwała chęć do życia w obecności Boga i ku Bogu - przejawiające się w religijnych uczuciach, intencjach, dążeniach i praktykach”27.

\section{Sposoby pedagogizacji}

Ważną rzeczą jest wiedzieć nie tylko, co należy czynić, ale jak czynić i przy pomocy jakich metod i środków. Kształcenie rodziców pozostaje dla Kościoła ciągle jeszcze nowym terenem działalności. Nieustannie powraca pytanie: jakimi drogami Kościół ma iść? Duszpasterze i katecheci, włączeni w proces pedagogizacji rodziców, powinni uczynić przedmiotem stałej refleksji i wnikliwych dociekań nie tylko treść, ale i sposoby pedagogizacji. Korzystać przy tym powinni z doświadczenia pedagogów praktyków. Pedagogika rodziny $^{28}$, pedagogika dorosłych ${ }^{29}$, katecheza dorosłych ${ }^{30}$, jak też katecheza rodzinna $^{31}$ wypracowały pewne metody pracy $\mathrm{z}$ dorosłymi, które należy

${ }^{26}$ Por. Tamże, s. 272.

${ }^{27}$ Tamże, s. 273.

${ }_{28}$ Por. J. Wilk, Pedagogika rodziny. Zagadnienia wybrane, Lublin 2002; S. Kawula, J. Brągiel, A. W. Janke (red.), Pedagogika rodziny. Obszary i panorama problematyki, Toruń 1998, s. 317-318.

29 Por. O Czerniawska, Ksztatcenie dorostych a środowisko rodzinne, Warszawa 1970; W. Szewczyk, Uczenie się dorostych, w: W. Okoń (red.), Teoria i praktyka upowszechniania wiedzy, Warszawa 1979, s. 91-103; J. Nowak, A. Cieślak, Edukacja dorostych w Polsce i na świecie, Warszawa 1982; L. Turos, Andragogika ogólna, Siedlce 1993; T. Wujek (red.), Wprowadzenie do pedagogiki dorostych, Warszawa 1992.

${ }^{30}$ Por. K. Misiaszek (red.), Katecheza dorostych we wspólnocie Kościoła, Warszawa 2002; M. Majewski, Aktualne wyzwania katechetyczne, Kraków 1997.

${ }^{31}$ E. Osewska, J. Stala (red.), Drogi katechezy rodzinnej, Poznań 2002. 
uwzględnić w procesie wychowania rodziców. Jeśli Kościół chce wyjść naprzeciw potrzebom współczesnego człowieka, a musi to zrobić, by rzeczywiście nieść pomoc, powinien podjąć wysiłek organizowania kontaktu z rodzinami. Nie można bowiem zapominać, że wszelka praca duszpasterska, a także cała praca kształceniowa, jest w gruncie rzeczy tylko propozycją.

Kształcenie rodziców jest częścią ogólnego procesu kształcenia dorosłych i słusznie traktuje się je jako bodziec do dalszego samokształcenia. Jak oceniają pedagodzy, specjaliści z omawianej dziedziny, doskonalenie rodziców pod względem pedagogicznym w naszym kraju jest dość zaniedbane i realizuje się je połowicznie, dorywczo i to głównie drogą inicjatywy różnego rodzaju instytucji społecznych, w tym także parafii ${ }^{32}$. Obie strony współpracujące muszą dołożyć wysiłku i wzajemnie się wspierać, by osiągnąć wyznaczony cel. Niestety, w kręgach kościelnych pokutuje błąd, polegający na bezskutecznym przenoszeniu metod wychowania dzieci i młodzieży do pracy z dorosłymi.

Czas realizacji doskonalenia rodziców powinien przypadać na taki dzień i taką porę, które by zapewniły największą frekwencję. Wydaje się, że najodpowiedniejsza byłaby niedziela; czy każda, czy co druga w miesiącu, to już zależeć będzie od programu ułożonego przez miejscowych duszpasterzy. Wiadomo jednak, że trzeba wybrać któreś z nabożeństw w niedzielę, najbardziej dogodne dla rodziców i z nim powiązać konferencję o wychowaniu. Najpierw należy przygotować rodziców do takich konferencji drogą przekonania ich o potrzebie i konieczności pedagogizacji, a następnie rozpocząć cykl konferencji realizujących ją. Należy pamiętać, że będą i tacy spośród rodziców, którzy nie przyjdą; jeśli jednak należą do wspólnoty parafialnej, trzeba ich indywidualnie zaprosić, a kiedy i to nie poskutkuje, trzeba ich odwiedzić i nawiązać z nimi kontakt w sposób delikatny i życzliwy, bez robienia im wyrzutów. Chodzi bowiem o to, ażeby możliwie wszystkich rodziców objąć informacją pedagogiczną.

Należy dążyć do tego, aby informacje o dziecku, rodzicach, o tym, co należałoby przekazać dziecku oraz o samym procesie wychowawczym, nie były przekazywane dopiero rodzicom, ale już kandydatom na przyszłych rodziców, czyli dorastającej młodzieży. Wydaje się też, że w konkretnej pracy pedagogizującej już etap wstępny kształcenia rodziców może odbiegać od powyższej tematyki. Należałoby na początku omawiać tematy aktualne, w miarę możności pokrywające się z zamówieniem społecznym.

Natomiast uświadamianie pedagogiczne młodzieży można realizować w punkcie katechetycznym lub w kościele, w czasie dla niej najodpowiedniejszym. Sposób duszpasterskiego przygotowania do małżeństwa i obowiązków rodzicielskich, w tym do wychowania potomstwa, wytyczają w Polsce instruk-

${ }^{32}$ Por. S. Kawula, Kultura pedagogiczna rodziców jako czynnik stymulacji rozwoju i wychowania młodego pokolenia, w. S. Kawula, J. Brągiel, A. W. Janke (red.), Pedagogika rodziny. Obszary i panorama problematyki, Toruń 1998, s. 317-318. 
cje Konferencji Episkopatu Polski, a zwłaszcza Dyrektorium Duszpasterstwa Rodzin. Ten ostatni dokument, opracowany przez Radę do Spraw Rodziny i wydany dnia 1 maja 2003 roku, jest wynikiem ustawicznej troski Kościoła w Polsce o małżeństwa i rodziny, podejmowanej od kilkudziesięciu lat. Zbiera i porządkuje zasady i praktyki stosowane w tym duszpasterstwie od dawna oraz proponuje nowe rozwiązania. Podstawowy wysiłek skierowany jest na to, by małżeństwa i rodziny były prawdziwie chrześcijańskie. Znaleźć w nim można konkretne wskazówki do pracy wychowawczej z rodzinami; mówi on m.in. o poradnictwie rodzinnym: „Wobec narastających zagrożeń małżeństwa i rodziny z jednej strony i wobec coraz trudniejszych wyzwań, stających przed rodzinami zdrugiej, należy organizować pomoc rodzinom wodpowiednio szerokim zakresie. Jedną z form pomocy narzeczonym, małżonkom i rodzicom, jest kompetentne poradnictwo rodzinne, łączące fachowość doradców z ich osobistym świadectwem życia Ewangelią" (Dyrektorium, 37).

Poradnictwo jest ważnym elementem duszpasterstwa. Musi objąć całą strukturę rodziny, wszystkie jej elementy oraz role i funkcje, a nawet przygotowanie do życia małżeńskiego i rodzinnego. Wśród szerokiego zakresu zadań Katolickiej Poradni Rodzinnej wymienia się szczególnie: ukazywanie właściwego wymiaru miłości małżeńskiej i rodzinnej, kształtowanie postaw prorodzinnych; nauczanie zasad odpowiedzialnego rodzicielstwa; pomoc w rozwiązywaniu konfliktów małżeńskich i rodzinnych oraz problemów wychowawczych i religijnych $^{33}$. Dlatego poradnia, jeśli ma skutecznie pomagać rodzicom w pracy nad wychowaniem dzieci, winna być poradnią nie tylko dla nich samych, ale i dla ich dzieci. Poradnia powinna im w tym pomóc nie tylko wtedy, gdy się do niej zgłoszą rodzice, ale też wychodzić im naprzeciw. Episkopat poleca, aby »w każdej parafii zadbać o umieszczenie w programie duszpasterskim katechez, głoszonych systematycznie małżonkom i rodzicom, np. co miesiąc" (Dyrektorium, 52). Proboszcz może, a nawet powinien, co jakiś czas zlecać przeprowadzenie takiego spotkania pracownikom poradni, dobrze przygotowanym do omawiania problemów komunikacji małżonków ze sobą i z dziećmi, do pomocy w rozwiązywaniu ich kłopotów małżeńskich i wychowawczych oraz do wspierania ich na drodze chrześcijańskiego życia radą i świadectwem.

Jeżeli chodzi o inne metody pracy wychowawczej z rodzicami stosuje się najczęściej: rozmowę indywidualną, odczyt, wykład, pogadankę, film, dyskusję oraz opracowywanie literatury pedagogicznej ${ }^{34}$. W pedagogizacji chodzi bowiem głównie o budzenie postawy rodziców do wytrwałego poszukiwania i celowej nieustępliwej walki o polepszenie sytuacji rodzinnej. A sprawić to może aktywna dyskusja czy pogadanka. W parafialnej i diecezjalnej pedagogizacji rodziców te metody pracy będą prawdopodobnie bardziej skuteczne niż

\footnotetext{
${ }^{33}$ Por. G. Koszałka, Poradnictwo rodzinne. Organizacja i przygotowanie kadr, „Sprawy Rodziny" 2003, nr 61-62, s. 111-117.

${ }^{34}$ Por. K. Kotłowski, O pedagogicznym ksztatceniu rodziców, Warszawa 1968, s. 129-157.
} 
wykład, odczyt czy konferencja. Innymi sposobami pracy, od dawna z powodzeniem stosowanymi i przynoszącymi oczekiwane skutki, są ćwiczenia rekolekcyjne, dni skupienia i nabożeństwa przygotowywane specjalnie dla rodziców ${ }^{35}$. Mogą one być związane oprócz stałych, z góry wyznaczonych terminów, z uroczystością Św. Rodziny, dniem Pierwszej Komunii Św., Dniem Matki itp.

Otwartym zadaniem jest ustalenie, kto ma udzielać informacji o dziecku, rodzicach czy procesie wychowania rodziców i kandydatów na rodziców. Jak twierdzą niektórzy autorzy, powinny to być osoby znające zagadnienia zarówno od strony teoretycznej, jak i praktycznej, a jednocześnie cieszące się wysokim autorytetem w danym środowisku. Aby jednak duszpasterstwo rodziny mogło przynosić owoce, powinny się weń włączyć wszyscy, którzy mają bezpośredni lub pośredni kontakt z rodzicami.

Pedagogizacja rodziców, propagowana przez Kościół, jest jedną z form pracy duszpasterskiej, dlatego też pracę tę mogą prowadzić, na mocy sakramentów chrztu i bierzmowania, nie tylko duchowni, ale i świeccy dobrze do tego przygotowani. Osoby zajmujące się prowadzeniem pedagogizacji powinny być do tej pracy odpowiednio przygotowane ${ }^{36}$. Winni to być ludzie o wysokim poziomie etycznym. Do niejednego zadania osoba świecka bywa bardziej pożądana niż duchowna, zwłaszcza w zakresie medycyny, psychologii czy innej specjalności dotyczącej życia świeckiego. Rozmaitość prelegentów, fachowo przygotowanych, doda powagi i znaczenia samej pedagogizacji, która być może urośnie do rangi ogólnej i powszechnej.

\section{Zakończenie}

Na rodzicach spoczywa główny ciężar odpowiedzialności za wychowanie dziecka. Z poczucia tej odpowiedzialności powinno płynąć ich zainteresowanie sprawami właściwego wychowania potomstwa. Zadanie to bowiem jest sztuką wymagającą dużych umiejętności. Rodzice więc nie mogą polegać wtym względzie wyłącznie na swoich zdolnościach wrodzonych. Powinni stale doskonalić i zdobywać umiejętności wychowawcze, jak i wszelkie inne rodzaje umiejętności. Tymczasem wychowanie dzieci jest dziedziną, do której niewielu rodziców przygotowuje się w sposób systematyczny. Nierzadko ich świadome, intencjonalne zabiegi wychowawcze są w sprzeczności z ich postępowaniem i stylem życia, a wtedy są nieskuteczne.

W niniejszej pracy sugerowano więc, by pomoc rodzicom w zakresie wychowywania potomstwa niósł także Kościół. Niewielu, niestety, pedagogów zajmujących się tą problematyką wymienia go jako podmiot realizujący tego typu działalność. Tymczasem oczywistym zadaniem Kościoła winno być

${ }^{35}$ T. Kukołowicz, Pedagogizacja rodziców w duszpasterstwie parafialnym, „Sprawozdania Towarzystwa Naukowego KUL" 15 (1965), s. 70-71.

${ }^{36}$ Por. A. Skreczko, Przygotowanie przyszłych kapłanów do duszpasterstwa rodzin w warunkach wspótczesnych, „Studia Teologiczne. Białystok-Drohiczyn-Łomża” 17 (1999), s. $121-134$. 
organizowanie poradnictwa i pedagogizacji rodziców oraz kandydatów na rodziców przy parafiach, dekanatach czy diecezjach. W niniejszym opracowaniu wykazano, że Kościół ma prawo i obowiązek to czynić. Kompetentna i długofalowa pomoc ma uświadomić rodzicom potrzebę pedagogizacji oraz zapoznać ich z zobowiązaniami płynącymi z zawarcia sakramentu małżeństwa, przekazać wiedzę o dziecku, o nich samym jako wychowawcach oraz o wychowaniu. Wiedza ta zapewne zmieniłaby ich stosunek do siebie i dziecka oraz do modyfikacji metod i środków wychowawczych. Byłaby to wielka szansa dla rodziców, jak też dla samego dziecka, a pedagodzy i duszpasterze mogliby po pewnym czasie spodziewać się odnowy rodziny oraz lepszej realizacji rodzicielskiego powołania przez małżonków. 